\title{
Pacific Universities' Leadership during the COVID-19 Pandemic- a Case Study of Fiji and New Zealand
}

\author{
Prashneel Ravisan Goundar ${ }^{1} \&$ Sherita Sharma ${ }^{2}$ \\ ${ }^{1}$ Department of Language \& Literature, Fiji National University, Fiji \\ ${ }^{2}$ The University of the South Pacific, Fiji \\ Correspondence: Prashneel Ravisan Goundar, Department of Language \& Literature, Fiji National University, P. \\ O. Box 5529, Lautoka, Fiji. Tel: 679-809-5747. E-mail: prashneel.goundar@fnu.ac.fj; sherita.sharma@gmail.com
}

Received: October 2, $2021 \quad$ Accepted: November 30, $2021 \quad$ Online Published: December 2, 2021

doi:10.5539/par.v11n1p1 URL: http://dx.doi.org/10.5539/par.v11n1p1

\begin{abstract}
The global education system came under scrutiny in 2020 due to the unexpected pandemic. COVID-19 forced higher education institutions everywhere to rethink the way to deliver classes or continue offering their services due to travel restrictions, lockdowns and social distancing policies. This caused major disruptions in carrying out normal teaching and learning. The intervention of university leadership in maintaining decorum during the pandemic entailed making pivotal decisions within a short period of time. The aim of this paper is to highlight various statements made by a group of universities from Fiji and New Zealand to present their position, and policies during the global pandemic. This article discusses how university leaders in the South Pacific with a case study of Fiji and New Zealand have responded to the pandemic. It discusses the statements and media releases of university leaders in Fiji (a developing nation) and New Zealand (a developed nation), particularly their responses and comments on the mode of teaching, international travel, social distancing, financial impact, and research. These focus areas need to be priority for university leaders in making crucial decisions in operating higher education institutions during unexpected events such as the pandemic.
\end{abstract}

Keywords: COVID-19, vice-chancellor, Fiji, university leadership, higher education, South Pacific

\section{Introduction}

2020 became a year of unpredicted events where a global transformation occurred in various sectors including environmental impacts, unemployment rates, with increase crime rates as well as the way education has had to reorganise itself. The 2019 Novel Coronavirus, better known as the COVID-19 pandemic has put universities in the spotlight in responding to the call of extreme measures, while addressing the needs of students. Governments lockdown and restrictions put in places around the world have forced universities to think creatively and innovatively to revamp the learning and teaching processes.

Even though leaders in higher education had been adapting to technological changes over the decades, the pandemic pushed for creative and drastic measures to be taken up almost overnight to align its operations to the crisis. Universities had not been offering online teaching for most of their courses with the exception of a few. Even $\mathrm{PhD}$ or Masters by thesis programs were only run through face to face or on campus mode. However, with the global outbreak of the pandemic, university leaders and administration were forced to rethink about their program delivery.

This paper examines university leadership of two neighbouring South Pacific Island countries with diverse economic backgrounds during the start of the pandemic. Fiji is a developing country whereas New Zealand is a developed country but their similarities or differences in handling changes to polices in higher education can be studied, and adopted by other countries amid the pandemic. The article has adopted a case study approach to discuss the statements and media releases of university leaders in Fiji (a developing nation) and New Zealand (a developed nation), particularly the way they have responded to the mode of teaching, international travel, social distancing, financial impact, and research.

Case studies are used to describe something in detail (Day Ashely, 2012, p. 102). The case study approach is different from 'a variable led research' as it focuses on 'the complex interaction of many factors in few cases' rather than having many variables in a large number of cases (Day Ashely, 2012, p. 102). Thus, the authors of the 
paper opted to take a multi bound case study design in reporting the findings of this study.

The study includes all three universities in Fiji that provide tertiary education up to Doctor of Philosophy - PhD level: The University of the South Pacific, which is a regional provider with campuses in 14 Pacific countries altogether, the largest centre being in Laucala, Suva, Fiji's capital city in the Central Division, as well as two other Fiji campuses in Labasa (Northern Division) and Lautoka (Western Division); the Fiji National University, which provides technical and vocational education and training (TVET) and a wide range of higher education programmes through its 12 campuses across Fiji, while the University of Fiji is a privately-run institute, established by the Arya Pratinidhi Sabha of Fiji, and has two campuses in Suva and Lautoka.

This research focused on capturing the impact of COVID-19 on tertiary institutes in three main geographical locations in New Zealand - Dunedin-based University of Otago on the South Island, which is a well-known medical institution regionally and internationally; Victoria University in New Zealand's capital city Wellington, which has a diverse range of courses and a wide reach; and University of Auckland, in Auckland on the North Island, which also caters to a large population of students from across the country as well as Pacific islanders and international students.

Having looked at the problem of practice in this introduction, this paper moves to the research questions before highlighting relevant literature in this field. Thereafter, the paper discusses the methodological approach, the way data was collected and reports on the findings. Finally, the paper concludes by summarising the study and providing implications for further research.

\section{Research Questions}

1) What measures were taken by the university leaders in Fiji and New Zealand in adopting to the learning and teaching needs during COVID-19?

2) What media statements were made by these universities to present their position, and polices during the global pandemic?

3) What lesson can developing and developed countries university leaders learn from these two countries?

\section{Research Objectives}

The objectives of this paper include:

1) to use a multi bound case study system to present the position, and policies of universities in New Zealand and Fiji during the global pandemic;

2) to refer to the media statements from university leaders in Fiji and New Zealand to investigate the priority areas that they addressed.

\section{Literature Review}

COVID-19 has propelled university leaders everywhere to explore creative solutions to continuing the delivery of higher education. This literature review examines the immediate impact of COVID-19 on universities and illustrates how university leaders globally have led during the pandemic and how their approaches have affected education delivery and quality.

\subsection{Challenges}

Undoubtedly, COVID-19 brought multiple challenges to the higher education landscape. The university community, students and staff have had to adapt and move to online platforms to conduct teaching and learning such as Zoom and Google Meet, as well as for mentoring, administrative, student services and research support. Brammer \& Clark (2020) reflected on challenges faced by universities because of COVID-19, mentioned that students were the "most affected stakeholder throughout the pandemic and were at the forefront of [businessstakeholders'] minds when designing and implementing responses" (p. 454). Students were particularly concerned about their study progress, graduation, first-year university experience, internships, study tours and exchanges and extra-curricular activities. They also identified repatriation of students overseas and study continuation for postgraduate researchers challenging (Brammer \& Clark 2020, p. 455).

Further, Pather et al. (2020, p. 289) analysed how anatomy educators in Australia and New Zealand were affected during COVID-19. They claimed that due to the pandemic there was a loss of integrated "hands - on" experiences. In addition, immediate changes to workload and teaching methods, as well as personal educational philosophies, as a result of remote teaching and learning. These outline the areas that need to be assessed by university leaders with priority when dealing with a crisis such as the pandemic. 


\subsection{New Opportunities and Approaches}

Despite the challenges, university leaders have tapped into opportunities to build more effective relations within the university communities. Brammer \& Clark (2020) emphasised communication, although challenging and complex at times, was the biggest breakthrough in the form of online engagement platforms such as Microsoft Teams and video conferencing tool Zoom. Whilst academia is a field of continuous learning, the abrupt arrival of the pandemic forced education leaders around the globe to take quick action which disrupted learning. This meant university leaders with years of experience had to immediately embrace and incorporate new technology such as online conferencing, mobile and web service platforms to continue delivering education services.

Leaders had to relearn and upskill, at times learning from their own students. The change in dynamics has prompted leaders to continue upskilling while upskilling others. Despite its challenges, Pather et al. (2020, p. 290) found that remote online education provided opportunities to "enable synchronous teaching across remote sites, expand offerings into the remote learning space, and embrace new pedagogies". McGuire et al. (2020, p. 367) attest that New Zealand Prime Minister's approach to crisis communication, presented how it is critical for leaders, across all fields, to connect clearly, emotionally and psychologically with people in order to shape perceptions of the crisis.

Innovation was another opportunity, with everyone not only adapting to and exploring new pedagogical methods but also creating a connected and interdependent community. This implies providing professional and emotional support, professional development, and training during the "new normal" (Brammer \& Clark 2020). The biggest opportunity has been that of developing and implementing best practices within education during times of crisis.

\subsection{Leadership Attributes}

Psychologists Lawton-Misra \& Pretorius (2021) have discussed the effects of COVID-19 on university leadership through a psychological dimension, postulating that "[t]he pandemic is requiring us to unlearn old behaviours, teachings, and philosophies, and relearn skills and attitudes from scratch". They also identified that leaders have had to demonstrate qualities such as empathy, compassion, vulnerability, self-awareness, sensitivity and agility to navigate the new working environment (Lawton-Misra \& Pretorius, 2021).

Dumulescu \& Muţiu (2021) also talked about how leaders have to "act under high psychological pressure, with great expectations from members of various organizations for constant reassurance and support. Moreover, the pressure of time, ambiguity, the lack of information, and high level of stress, all increase the difficulty of the decision-making process". Essentially, university leaders had to take on a holistic crisis-response approach, including understanding personal circumstances of staff and students to make strong and effective decisions to lead universities. Dumulescu \& Muţiu (2021), observed leadership at the Babeş-Bolyai University in Romania and found that the leaders' personal attributes have helped the university adopt the strategy of unity through decentralization and presented opportunities to reinvent the university through trust, and these new ways of working.

The review of literature has revealed the gap that within the Pacific particularly for Fiji and New Zealand is very limited research has been conducted in relation to the impacts of COVID-19 on university leadership and the approaches leaders have taken to continue with education delivery. Therefore, the objective of this study is to fill the gap.

\section{Methodology}

This research was conducted between March 2020 to September 2020. The criteria of selecting universities that was set by researchers was to include universities in New Zealand and Fiji which had similarity in leadership structure, program offerings, and geographical spread. Further, in order conduct this study a method that could allow gathering of data through analysing statements and making comparison was required. Thus, as highlighted in the introduction, a multi bound case study approach was taken in collecting and analysing data in this study. According to Bassey (1999), 'case study research allows for a certain degree of methodological eclecticism which typically includes analysing documents'. Thus, media statements from university leaders in Fiji and New Zealand were used in gathering data. The data collected was categorized or grouped in the similarities found between the universities in New Zealand and Fiji.

The universities studied are: The University of the South Pacific (USP), Fiji National University (FNU), University of Fiji, University of Otago, Victoria University of Wellington, and University of Auckland as well as Universities New Zealand- a local consortium of universities, of which the last three institutions are members of. The methodological approach used to conduct this research was through online research and desktop study; by visiting university websites for media releases, Vice-Chancellor updates and other statements, as well as online news 
reports by news-media organisations. This approach provided quick and reliable access to information within a short period of time that enabled the timely production of this research paper. Limitations included the lack of regularly updated information on websites, and at times, the lack of statements and comments made available to the public, especially in the case of Fiji, which led to the use of manual searches through online search engines.

The information collected was first categorised into the five focus areas. This method of grouping helped to determine the similar or different challenges and opportunities faced by universities as shared by university leaders, and their approaches to the situations that arose.

\section{Findings and Discussions}

\subsection{Mode of Teaching}

The biggest challenge for universities in Fiji was the mode of delivering classes. All three major universities in Fiji - University of the South Pacific, Fiji National University, and The University of Fiji - changed their teaching from face to face and blended learning to online delivery. The Acting Vice-Chancellor of the University of Fiji, in a statement released on 15 May 2020 stated that "We will not allow the COVID-19 calamity to deter us from our primary role at UniFiji, that is, to teach and to learn. We will win this war on our own terms, by being as resourceful as we can" (Unifiji.ac.fj, 2020). She further stated that due to public health risks, it was prudent to move from face to face classes to online. However, an assessment of staff capabilities should have been carried out prior to the implementation of this policy to ascertain if the academic staff had adequate experience in delivering programs in online mode.

The University of the South Pacific (USP) had to extend its mid-semester break to address the mode of delivery. Usually the break is for a week, but their break extended for over a month with suspension of any tests, assessments or classes through any form of delivery. This became a challenge for all registered students as well as the lecturers to proceed with the semester plan. After considerable deliberations, USP then resumed classes on 20th April through remote learning mode. The Vice-Chancellor and President announced the changes through a Staff and Student Advisory that all undergraduate programs which were not externally accredited would proceed with $100 \%$ coursework without having any final examinations (usp.ac.fj, 2020).

The leaders of Fiji National University directed all the teaching staff to prepare to teach online using the Moodle Learning System and extended their mid-semester break following the dates closely with USP. Acting ViceChancellor of Fiji National University, announced that classes would commence from 20th April 2020 but through online mode and advised against face to face teaching. He also clarified to the lecturers that "If any of your units have assessments in them requiring field trips or collection of field data for assessments to be undertaken in the next half of this semester, then these have to be changed" (fnu.ac.fj, 2020).

New Zealand universities were also quick in taking their educational services online. Following the Government's advice in March 2020, the University of Otago in Dunedin fast-tracked its move to online teaching, saying in a statement: "With face-to-face teaching no longer possible, the University is suspending all teaching immediately and is aiming to return with online learning as soon as possible" (University of Otago, 2020). Students, on and off campus, gained immediate access to continue their learning online in a flexible manner, with Vice-Chancellor commenting: "The irony here is that "boomer" generation has been asked to support the "zoomer" generation to learn online. I am sure both groups will learn more about the other in the process; our students will teach us as much as we teach them under these unprecedented conditions" (University of Otago, 2020).

She further encouraged them to continue supporting each other by staying connected through digital platforms such as email, the online newsletter Otago magazine, Facebook, and LinkedIn (University of Otago, 2020). Staff were also fully supported through working from home, and as essential workers, with resources provided on "managing the move to working from home, including looking after mental health and well-being", and the establishment of a HR COVID-19 contact centre (University of Otago, 2020). The Vice-Chancellor said: "We are living in exceptional times, and I very much appreciate the resilience of our students and staff as we adapt to this changing situation" (University of Otago, 2020). While describing "dealing with fallout from the COVID-19 pandemic as an emotional rollercoaster", she thanked the University family for supporting each other has helped everyone during the pandemic and celebrating a united front in the face of adversity, despite the cancellation of important calendar events, including four graduation ceremonies (Otago Daily Times, 2020).

In addition to moving its existing courses online, Victoria University started offering free education to people affected by COVID-19, with a scholarship covering 100 percent of tuition fees for new students in July 2020 (RNZ Newshub, 2020). The Vice-Chancellor said, "Whether that be losing a job, or being forced to be home to look after a dependant or being forced back here to the city from overseas as a result of COVID-19, it was a simple thing we 
could do to support the community in a time of need," (RNZ Newshub, 2020). This effort to support local communities shows the level of importance placed by university leaders even in such difficult times.

In March, the University of Auckland announced that staff and students (excluding those in research, placement or practicum) were advised that 23 to 27 March was a "Teaching Free Week" with students "not required to attend but could if they wished to... the university is therefore preparing for a scenario in which teaching would continue even if students are unable to come onto campus. A range of remote learning technologies and practices would be deployed for students, [and on-campus support including support guides and drop-in clinics], while staff continue to work as normal on campus" (Radio New Zealand, 2020). The statement also advised that scheduled tests would be "postponed and replaced by off-campus assessment exercises", semester timings may shift, and core student services such as "libraries, Kate Edger Information Commons, AskAuckland Central, Recreation Centre, retail outlets, and the student accommodation, [would] continue to operate" until advised to close (Radio New Zealand, 2020).

Even though the university leaders tried best to manage the unexpected situation, a lot of valuable time went into preparation which caused delay of exams and assessments. In April, the University of Auckland's Vice-Chancellor, in her update talked in detail about the University's remote learning plan, aligned to the Government's different alert levels, including maintaining remote learning until at least the start of Semester Two in July (University of Auckland, 2020). The timely issuing of these university leaders' statements, immediately after national announcements, indicates the awareness these leaders have of the significance of sharing relevant information with stakeholders on how the mode of studying has been affected by COVID-19.

Universities New Zealand (UNZ) Director, said its members are doing their best to put as many courses as possible online but there are challenges with more hands-on delivery models, especially in the long term. "We know it's going to be pretty easy to put lectures online but a lot harder to be able to support students in much more practical programmes where there is a need - say, in engineering or medicine - for access to laboratories or workshops. "So we can do workshops and laboratories with smaller groups of students, while respecting the social distancing guidelines, but removing the need for a large number of students or staff to gather" (Radio New Zealand, 2020).

\subsection{International Travel Restrictions}

An integral part of a university is attending international conferences, as well as having expatriate staff such as visiting fellows, researchers and professors and international students. However, the pandemic changed the dynamics of travelling abroad almost overnight. Apart from the University of Fiji, the other universities in Fiji had clear instructions on travel restrictions. The University of the South Pacific was the first to give directives to the members of staff from travelling to China and Hong Kong as they put a complete ban on traveling there. Then, effective from 16 March 2020, the USP Occupational Health and Safety team put a ban on international travels. On the contrary, no effort was made to have a contingency plan for the replacement of the expatriate staff. These staff are of extreme value to the university and effort should be made in maintaining them.

A similar stand was taken by Fiji National University and the leaders put a ban on international travel with immediate effect from 16 March 2020. FNU clarified further on the travel restrictions and stated that "if you have to travel to countries affected by Fiji's current travel restrictions, please note that you will need to include in your annual leave request an additional 14 days after your return to cover the period for which you will be required to self-quarantine" (fnu.ac.fj, 2020). This strategy of university leadership is worth employing in future Human Resource matters.

In New Zealand, there has been a call to provide greater support for international students stranded in their home countries or overseas and were unable to travel to New Zealand due to strict border restrictions. The University of Otago's Pandemic Committee discussed possible solutions to support the University's move to full online learning which secured the continuation of studies for all students including international students (University of Otago, 2020). Challenges for the University's International Office included over 200 students in China, 1,800 international students already in New Zealand and wanting to return home. Close to 400 students decided to return home over a two-week period, with only some returning to study online. The dynamics of interacting changes ad well with international students checking in through "daily Zoom cafes and welfare checks by phone" (University of Otago, 2020).

In February, Victoria University's Vice-Chancellor who also leads the UNZ committee on international policy, said universities would be able to manage international student arrivals as protocols are in place. He said it was just as important to address this as early as possible with "hundreds of millions of dollars [on the line]". "There is no doubt based on the evidence that this can be managed, but of course, we are in a highly political environment and we've got people's understandable anxieties to take into account" (Radio New Zealand, February 2020). 
University of Auckland's Vice-Chancellor said "there had been an outstanding response to support some 2,000 students stranded in China by the travel ban", adding that while she was confident the University teaching over 40,000 students remotely, including these international students, even though it "was a new step" (Radio New Zealand, 2020). She added, "We are also very aware of the challenges to the continued delivery of our research commitments, which will also need some careful consideration. Suspending teaching activities for next week provides an opportunity for our staff to focus fully on these areas of core business and to adapt and adopt through creative problem solving and collaborative working" (Radio New Zealand, 2020).

He spoke strongly about the UNZ's stance on developing "a credible plan to bring back students", especially with the government's untimely announcement of not allowing international students back in the following semester (The Pie News, 2020). "There hasn't been any advice from the university or the government and how they're handling $\mathrm{PhD}$ students, doctoral candidates and researchers. Because our stuff is time-sensitive and it requires ethics and guidelines, and peer reviews and networks with our supervisors - it's not something we can sit online and do." He added a lot of things at stake within the $\$ 5$ billion-a-year industry which "creates tens of thousands of jobs in this country. So getting it restarted is important for New Zealand but getting it restarted safely is also important" (The Pie News, 2020). However, the association stated universities are working closely with government agencies to prepare for the return of these students. "We do believe New Zealand's handling of the outbreak will make it an even more attractive place for students from other countries than it already is, but this is likely to be a longer-term prospect, rather than a short-term one" (The Pie News, 2020).

\subsection{Social Distancing and Social Gathering}

The first of the government alerts was to restrict social gathering to 20 members only which was changed to 100 people at the end of June 2020. However, this came a bit late as universities in Fiji were already into the examination period and classes had already finished. All universities in Fiji made a stern decision to refrain from social gathering and practice social distancing. The adverse effect of social gathering policies meant not having face to face classes, laboratory practical or practicum components for teaching major students. This deferred the completion of studies for many students who were anticipating the semester to be last but would have to wait another year to complete their program of study.

Fiji National University management made it clear that "Staff are strongly requested not to engage in the normal social conventions of shaking hands or hugging during this period, to minimise their risk of infection" (fnu.ac.fj, 2020). As a preventive measure, the University of the South Pacific also indicated to everyone "All Staff and students are instructed NOT TO SHAKE HANDS, but use alternative NON CONTACT physical forms of salutations and greetings" (usp.ac.fj, 2020). On the contrary, the third major university in Fiji, The University of Fiji did not lay out clear guidelines in their public statements.

Universities in New Zealand put social distancing measures in place following the government's announcement on nationwide COVID-19 regulations. On 15 May 2020, the University of Otago welcomed back students to all its campuses and colleges. The Vice-Chancellor said, "I cannot speak highly enough of the way Otago students stepped up in the fight against COVID-19, just as they have in past crises this nation has known." With social distancing measures still in place, she advised students that it was imperative that students stick to the regulations and follow the Ministry of Health guidelines if they do not feel well or have any flu-like symptoms, as the University is determined to help New Zealand stay clear of COVID-19 (May 2020). She further reminded students of their "collective responsibility" and to be conscious of "physical distancing rules and limit gatherings to no more than 10 people" - in line with the Government's Alert Level 2 conditions.

The Vice-Chancellor advised social distancing at the Victoria University has been doable with "the institution already operating on a model which offered students choice over whether they attended a lecture in person or watched a video of the lecture from home" (Radio New Zealand, 2020). In her April update on remote learning, Vice-Chancellor said the University would still impose "stringent restrictions applied to physical distancing and sizes of groups, which we believe would severely disrupt effective on-campus teaching and learning, "[for campusbased activities]" (University of Auckland, 2020). She added, "There is also an important equity concern here. Some staff and students will find it much more difficult than others - due to personal circumstances, home environments and other factors - to shift between on and off-campus modes of work and study. We need to make sure we do not unfairly disadvantage some people over others. For these reasons, we want to give our staff and students clarity and certainty by making the commitment now to continue remote learning and closed campuses for the rest of Semester 1, regardless of the Government's alert level". Overall, all the universities put in place very strict restrictions, aligned to national restrictions on social distancing, coupled with remote learning, to minimise the spread of COVID-19. 


\subsection{Research and Recognition}

At present, there have been no discussions or media coverage on COVID-19-related research in Fijian universities. This could imply that Fijian universities gave priority to teaching and learning in the pandemic when compared to research work. However, New Zealand academics have publicly supported the government in responding to COVID-19 through academic ventures. As New Zealand's leading medical university, the efforts of University of Otago academics who are helping with COVID-19 have been recognised by the Director-General of health in a letter to the Vice-Chancellor (New Zealand Herald, 2020). Acknowledging the vision of the University's founders, The Vice-Chancellor said the University's contribution to the national fight against COVID-19 is "a cogent reminder of our proud and permanent place in society. When the Government needed expertise to guide their decision-making, they turned to experts at Otago... We will continue to assist where we can in the fight against COVID-19 and we look forward to contributing to New Zealand's recovery" (University of Otago, 2020).

Immediate activities coming out of COVID-19 within the University's various departments include an in-house project led by the School of Pharmacy to produce 100 litres of hand sanitiser, enough for essential services on the University's Dunedin campus, surveying New Zealanders' attitudes towards government during these times, sewage and infection, virus testing. University of Otago researchers will also receive over \$26 million in funding to conduct COVID-19-related studies, including the connection between infectious diseases and long-term conditions, working towards developing vaccines, as well as a separate grant to maximise the health and wellbeing gains from housing (June 2020). A move such as this, by the university leaders should be applaud for being efficient in responding to the pandemic. Academics such as Dr Ayesha Verrall has been answering virus-related questions during regular Facebook Live sessions, while leading epidemiologist, Professor Michael Baker is directly informing Government policy and was recently awarded a $\$ 500,000$ Government grant for a project to guide an effective and equitable pandemic response and to learn as much as possible, so New Zealand is better prepared for the next major public health emergency.

Another important contribution to New Zealand's COVID-19 response is New Zealand's bubble concept. The concept to explain social distancing while advising the Ministry of Health on the COVID-19 response for the disability sector. The Vice-Chancellor is also among global university leaders who will discuss the COVID-19 pandemic and the future of international education in an online forum in early July (University of California, Davis, 2020). The proud Vice-Chancellor said: "It's a really good testament to the 150 -year tradition that there are so many fundamental values that the University holds that did allow us to continue to exist and in some ways flourish during an international pandemic. Think of the amazing contributions that University of Otago staff made to the Government's decision-making - and this is a government that's being held up worldwide as Best in Show. I personally feel very fortunate that the same people who were advising the Prime Minister were also advising me" (University of Otago, 2020).

Victoria University researchers conducted a national survey on how families in New Zealand fared during the COVID-19 lockdown and lessons, which highlighted key challenges including work and home situations, health and wellbeing, quality family time including childcare and gender equality in parental roles (Victoria University, 2020). The University through its Wellington UniVentures commercialisation office and the Ferrier Research Institute is also pulling together its resources to ensure New Zealand's access to anti-viral drugs for COVID-19 by identifying "promising existing anti-virals early, understand how they are made and manufactured, and look to source and secure them for New Zealand" (India Education Bureau, 2020).

The University of Auckland's academics have also been contributing to COVID-19 research. One of the Associate Professor's is his supporting research into the development of vaccines to combat COVID-19 (Deguara, 2020). The university's most recent partnership is a teaching and research collaboration with the Pennsylvania State University, eight research projects that each have received a "Collaboration Development Seed Fund Grant of up NZ\$20,000, equally funded by both universities" (Scoop, 2020). Most of the projects are focused on advancements in science and engineering, including the development of an app on Asian multicultural identity, headed by the Experiential Digital Global Engagement (EDGE) Collaboration lead, while another project will look at connecting students from the universities through "joint teaching". In terms of conducting research activity at the University of Auckland, Vice-Chancellor advised it will "remain mainly off-campus", where possible with "some on-campus research activities that may be allowed by Deans "on the basis that Level 3 operating protocols, including physical distancing and health and safety requirements, can be met" (University of Auckland, 2020).

\section{Conclusion}

This paper has presented the position, and policies of universities in Fiji and New Zealand as a multi bound case study at the arrival of the COVID-19 pandemic in the South Pacific, using press releases, media reports and 
statements of university leaders. The major ones include: the mode of teaching, international travel restrictions, social gathering restrictions, financial obligations, and research and recognition. University leaders of developing and developed countries can be challenged at any time of the teaching year due to unpredicted events such as the pandemic. It is crucial how leaders of both economic backgrounds tackle these necessary changes in order to continue running the universities.

From the findings of this study, a recommendation is to further develop the research by extending focus groups to include leaders of university students' associations and stakeholders such as government counterparts, who can provide their perspectives and share their observations on the implications of and academic approaches to COVID19. This approach would add increased value to the research, making it more rounded, and will cater to the needs of audiences who would want to know firstly; how the direct beneficiaries of university education have been affected by COVID-19 and resulting institutional policies and secondly; how involved governments have been in the shaping of these policies and approaches and how it has affected the implementation of national decisions on COVID-19.

The discussions put forward in this article also reflect the need to initiate a focus group approach that builds conversation on the gaps identified in the earlier parts of this paper. A roundtable discussion with a focus group of university leaders will strengthen the bond and operating capability of tertiary institutions as a shared goal.

A crisis such as the COVID-19 pandemic puts a lot of pressure on university leaders, teaching and administration staff, stakeholders, parents as well as university students to progress in their studies normally. This research indicated that the normal practice as shown in the earlier parts of this report needs to be quickly reassessed and evaluated. This research relied on media statements of university leaders in collecting data. However, future research can explore online interviews or surveys with university leaders or management teams in looking at the progress made months after the pandemic.

Finally, this study has provided a starting point for university leaders to reassess their plans for pandemics and unplanned events. They can carry out assessments of their own university operations during a global crisis and evaluate their responsiveness as well as preparedness.

\section{References}

Bassey, M. (1999). Case study research in educational settings (Doing Qualitative Research in Educational Settings) (1st ed.). Open University Press.

Brammer, S., \& Clark, T. (2020). COVID - 19 and management education: Reflections on challenges, opportunities, and potential futures. British journal of Management, 31(3), 453. https://doi.org/10.1111/14678551.12425

Collins, S. (2020, September 21). Covid 19 coronavirus: University of Auckland asks contract staff to work for no pay. NZ Herald. Retrieved from https://www.nzherald.co.nz/nz/covid-19-coronavirus-university-ofauckland-asks-contract-staff-to-work-for-nopay/HF6ULPD36YARISA6QO6CZ2I6UI/?c_id=1\&objectid=12328728

Covid-19 “emotional rollercoaster" for uni - Hayne. (2020, June 9). Otago Daily Times Online News. Retrieved from https://www.odt.co.nz/news/dunedin/covid-19-emotional-rollercoaster-uni-hayne

Day Ashely, L. (2012). Case study research. In Research Methods and Methodologies in Education (pp. 102-107). Sage Publications Ltd.

Deguara, B (2020). Coronavirus: What we know about Covid-19 transmission, testing, vaccines six months on. Retrieved from https://www.stuff.co.nz/national/health/coronavirus/122044870/coronavirus-what-we-knowabout-covid19-transmission-testing-vaccines-six-months-on

Dumulescu, D., \& Muţiu, A. I. (2021). Academic Leadership in the Time of COVID-19-Experiences and Perspectives. Frontiers in Psychology, 12. https://doi.org/10.3389/fpsyg.2021.648344

Fiji National University. (2020). About novel coronavirus. About Novel Coronavirus. Retrieved from https://www.fnu.ac.fj/new/article/4526-about-novel-coronavirus-covid-19

Goundar, P. R. (2019). Key Emerging Issues in Higher Education, Fiji. Asian Social Science, 15(6), 96. https://doi.org/10.5539/ass.v15n6p96

Harlene Hayne donates 20\% of salary to struggling students. (2020, April 24). Otago Daily Times Online News. Retrieved from https://www.odt.co.nz/news/dunedin/campus/harlene-hayne-donates-20-salary-strugglingstudents 
India Education Diary Bureau Admin. (2020, July 6). A group of New Zealand experts is coming together to ensure New Zealand has access to COVID-19 anti-virals. India Education | Latest Education News India | Global Educational News | Recent Educational News. Retrieved from https://indiaeducationdiary.in/a-group-of-newzealand-experts-is-coming-together-to-ensure-new-zealand-has-access-to-covid-19-anti-virals/

Lawton-Misra, N., \& Pretorius, T. (2021). Leading with heart: academic leadership during the COVID-19 crisis. South African Journal of Psychology, 0081246321992979. https://doi.org/10.1177/0081246321992979

Mcculloch, C. (2020, February 24). Universities make case for ability to handle students arriving from China amid Covid-19 outbreak. RNZ. Retrieved from https://www.rnz.co.nz/news/national/410269/universities-makecase-for-ability-to-handle-students-arriving-from-china-amid-covid-19-outbreak

McGuire, D., Cunningham, J. E., Reynolds, K., \& Matthews-Smith, G. (2020). Beating the virus: an examination of the crisis communication approach taken by New Zealand Prime Minister Jacinda Ardern during the Covid19 pandemic. Human resource development international, 23(4), 361-379. https://doi.org/10.1080/13678868.2020.1779543

Message to alumni and friends from Vice-Chancellor Professor Harlene Hayne. (2020). University of Otago. Retrieved from https://www.otago.ac.nz/alumni/news/COVID19update.html

Otago announces Pūtea Tautoko hardship fund for students. (2020). University of Otago. Retrieved from https://www.otago.ac.nz/otagobulletin/news/otago735854.html

Otago scientists secure more than $\$ 26 m$ for health research. (2020). University of Otago. Retrieved from https://www.otago.ac.nz/news/news/releases/otago739364.html

Otago Uni's message to students - no large parties during Covid-19 level 2. (2020, May 15). Stuff. Retrieved from https://www.stuff.co.nz/national/education/121522043/otago-unis-message-to-students--no-large-partiesduring-covid19-level-

2\#:\%7E:text=University\%20of\%20Otago\%20vice\%2Dchancellor,no\%20more\%20than\%2010\%20people. \&text=Gatherings\%20in\%20public\%20spaces\%20such,were\%20not\%20permitted\%2C\%20Hayne\%20said

Otago welcomes students back, seeking “collective responsibility.” (2020). University of Otago. Retrieved from https://www.otago.ac.nz/christchurch/news/otago736864.html

Pather, N., Blyth, P., Chapman, J. A., Dayal, M. R., Flack, N. A., Fogg, Q. A., Green, R. A., Hulme, A. K., Johnson, I. P., Meyer, A. J., Morley, J. W., Shortland, P. J., Štrkalj, G., Štrkalj, M., Valter, K., Webb, A. L., Woodley, S. J., \& Lazarus, M. D. (2020). Forced Disruption of Anatomy Education in Australia and New Zealand: An Acute Response to the Covid - 19 Pandemic. Anatomical Sciences Education, 13(3), 284-300. https://doi.org/10.1002/ase.1968

Responding to the global pandemic - Otago's story. (2020). University of Otago. Retrieved from https://www.otago.ac.nz/healthsciences/news/news/otago737012.html

RNZ News. (2020, March 20). Coronavirus: University of Auckland suspends teaching for next week. RNZ. Retrieved from https://www.rnz.co.nz/news/national/412202/coronavirus-university-of-auckland-suspendsteaching-for-next-week

RNZ Newshub. (2020). Coronavirus: Victoria University of Wellington offers free tuition to people impacted by COVID-19. Retrieved from https://www.newshub.co.nz/home/new-zealand/2020/03/coronavirus-victoriauniversity-of-wellington-offers-free-tuition-to-people-impacted-by-covid-19.html

Ross, J. (2020, June 9). No rush to the lecture hall in virus-free NZ. Times Higher Education (THE). Retrieved from https://www.timeshighereducation.com/news/no-rush-lecture-hall-virus-free-nz\#

Sector disrupted by the pandemic it helped fight. (2020, June 19). Otago Daily Times Online News. Retrieved from https://www.odt.co.nz/news/dunedin/sector-disrupted-pandemic-it-helped-fight

Shivangni, S. (2020, May 4). The University of Fiji tackles the Covid-19 crisis head on - The University of Fiji. University of Fiji. Retrieved from https://www.unifiji.ac.fj/the-university-of-fiji-tackles-the-covid-19-crisishead-on/

Stuff.co.nz. (2020a, May 6). Victoria University of Wellington's vice-chancellor Grant Guilford and senior leadership team take pay cuts. Stuff. Retrieved from https://www.stuff.co.nz/national/education/121431254/victoria-university-of-wellingtons-vicechancellorgrant-guilford-and-senior-leadership-team-take-pay-cuts 
Stuff.co.nz. (2020b, May 20). Coronavirus: Victoria University forges ahead with "employee gifting programme." Stuff. Retrieved from https://www.stuff.co.nz/national/education/121578817/coronavirus-victoriauniversity-forges-ahead-with-employee-gifting-programme

Stuff.co.nz. (2020c, July 7). Coronavirus: What we know about Covid-19 transmission, testing, vaccines six months on. Stuff. Retrieved from https://www.stuff.co.nz/national/health/coronavirus/122044870/coronavirus-what-we-know-about-covid19transmission-testing-vaccines-six-months-on

Te Herenga Waka-Victoria University Of Wellington. (2020, July 3). The parenting myth revealed by lockdown. Victoria University. Retrieved from https://www.newsroom.co.nz/ideasroom/the-parenting-myth-revealedby-lockdown

The PIE News. (2020, June 4). NZ considers options to bring international students back to its campuses. Retrieved from https://thepienews.com/news/nz-considers-options-to-bring-international-students-back-to-campus/

University Leaders to Discuss Pandemic, Future of International Education. (2020, June 30). UC Davis. Retrieved from https://www.ucdavis.edu/news/university-leaders-discuss-pandemic-future-international-education

University of Auckland. (2020). "VC Update 9 April 2020". Retrieved from https://www.auckland.ac.nz/en/students/student-support/remote-learning-support/vc-update-9-april2020.html

University of Otago (April 2020), 'Vice-Chancellor's Comment', University of Otago Magazine April 2020. Retrieved from https://www.otago.ac.nz/otagomagazine/otago735618.pdf

University of Otago responds to COVID-19 Alert Level rise. (2020). University of Otago. Retrieved from https://www.otago.ac.nz/christchurch/news/otago 734110.html

University of Otago. (2020, June 30). Fragile but beautiful: Otago academic's COVID-19 bubble concept. Retrieved from https://www.otago.ac.nz/medical-school/news/otago $739375 . h$ tml

University of the South Pacific. (2020). COVID-19 Pandemic 2020. Retrieved from https://www.usp.ac.fj/index.php?id=23655

University to reduce spending. (2020, June 22). Otago Daily Times Online News. Retrieved from https://www.odt.co.nz/news/dunedin/campus/university-of-otago/university-reduce-spending

Upset over news of international students not returning. (2020, June 29). Otago Daily Times Online News. Retrieved from https://www.odt.co.nz/news/national/rnz/upset-over-news-international-students-notreturning

\section{Copyrights}

Copyright for this article is retained by the author(s), with first publication rights granted to the journal.

This is an open-access article distributed under the terms and conditions of the Creative Commons Attribution license (http://creativecommons.org/licenses/by/4.0/). 